\title{
The Influence of Firm Size, Export Ratio and Earning Variablity On Firm Value with Economic Exposure as Intervening Variable in The Manufacturing Industry Sector
}

\author{
Thomas Sumarsan Goh \\ Accounting Department \\ The Methodist University of Indonesia \\ Medan, Indonesia \\ gohtho@gmail.com
}

\author{
Arthur Simanjuntak \\ Accounting Department \\ The Methodist University of Indonesia \\ Medan, Indonesia \\ as_smjt@rocketmail.com
}

\begin{abstract}
This study was carried out to test the influence of firm size, export ratio, and earnings variability on the firm value with economic exposure as an intervening variable in the manufacturing industry sector listed in the Indonesia Stock Exchange. The population of this study were 138 manufacturing companies listed in the Indonesia Stock Exchange within the period of 2011 2016, and 132 of the companies were selected to be the samples for this study through purposive sampling technique. The data were analyzed by using path analysis. The result of the research showed that the variables of Firm Size, Export Ratio and Earning Variability direct positive influence on Firm Value. Export Ratio and Earning Variability direct positive influence on Firm Value. Firm Size indirect positive influence on Firm Value. The variables of Exposure Economic as intervening variables to explain influence Firm Size on Firm Values.
\end{abstract}

Keywords - firm size; export ratio; earning variability; economic exposure; and firm value

\section{INTRODUCTION}

The rapid development of the world economy has enhanced interdependence and sharpened world business competition. This has encouraged the emergence of multinational companies involved in international activities and transactions. Especially, now at Asean Economic Community (AEC) that supports the international economic activities. Economic activities take place in the flow of goods, services and money in the world in accordance with economic principles. Such activities can not be separated from foreign exchange transactions. The demand for foreign exchange transactions occurs because of the need to convert currency from one country to other countries.

One of the risk from International Trading is uncertainty or fluctuation of exchange rate. Thus, the impact of exchange rate fluctuation phenomenon towards foreign currency especially US Dollar in year 2015 had reached Rp 17.000/ US Dollar. The unexpected exchange rate fluctuation had direct impact on sales, price, and profit of companies. Some companies had increased their values due to the rupiah exchange rate fluctuation and other companies had lowered their value. The variability of the value of the firms were caused by the unpredictable currency exchange rate fluctuation which had indicated the occurrence of economics exposure on various companies, if the companies had not handled the exposure, then it would decrease the value of the companies and would affect the performance of the companies and the employees.

This was caused by the company's flow of incoming or outgoing funds dominated in domestics currency would influence the interest expense of foreign debt would be higher. The fluctuation of Rupiah exchange rate against USD also effects the stock price. The influence of stock prices through the impact of exchange rate changes on cash inflows or outflows of the companies.

The study of Pritamani [1] had proved that the total economic exposure of the company was negatively related to the stock return rate, besides the economic exposure of the company was also influenced by the internal variables of the company with respect to its operations.

Anggreini [2] in her research entitled the Foreign Exchange Exposure at Go Public Banks on the Jakarta Stock Exchange, had used firm size as a proxy to measure the level of influence on the economic exposure of the company.

The fluctuations of rupiah exchange rate against the US Dollar had caused problems that would be faced by the companies in running their businesses. If the rupiah had weakened it would have benefited the exporters, on the contrary if the rupiah had strengthened, it would have benefited the importers. The significant strengthening of the rupiah exchange rate in a short time would cause problems for industries in Indonesia. 
Table 1

Export on Manufacturing Industry Period 2014-2016

\begin{tabular}{|c|c|c|c|c|}
\hline \multirow{2}{*}{ No } & \multirow[t]{2}{*}{ Name } & \multicolumn{3}{|c|}{ Total Export (Rp 000) } \\
\hline & & 2014 & 2015 & 2016 \\
\hline 1 & $\begin{array}{ll}\text { Asahimas } & \text { Flat } \\
\text { Glass Tbk } & \\
\end{array}$ & 977.573 & 1.082 .467 & 1.323 .033 \\
\hline 2 & $\begin{array}{l}\text { PT. Wilmar } \\
\text { Cahaya } \\
\text { Indonesia Tbk }\end{array}$ & 226.181 .776 & 283.646 .022 & 320.043 .621 \\
\hline 3 & $\begin{array}{l}\text { Primarindo Asia } \\
\text { Infrastructure } \\
\text { Tbk }\end{array}$ & 125.088 .415 & 142.743 .530 & 144.781 .606 \\
\hline
\end{tabular}

Table 1 had shown that each year the rate of exports had increased, indicating that foreign exchange transactions of three companies were increasing every year. So Foreign exchange exposure should be hedged. However only a few companies did it, they had only performed a natural hedge that was supplying foreign currency for payment when there were transactions with other countries. Based on the preliminary observations and interviews have found out that other firms had not hedged their foreign transactions because they assumed hedging was not good for their companies and hedging was like gambling.

Table 2

Foreign Currency Developments Period 2014-2016

\begin{tabular}{cccccc}
\hline $\mathrm{N}$ & \multirow{2}{*}{\begin{tabular}{c}
\multirow{\mathrm{o}}{*}{} \\
Value
\end{tabular}} & $\begin{array}{c}\text { Foreign } \\
\text { Currency }\end{array}$ & 2014 & 2015 & 2016 \\
\cline { 4 - 6 } 1 & 1,00 & USD & 12.396 & 13.187 & 13.443 \\
\hline 2 & 1,00 & JPY & 103 & 114 & 117 \\
\hline 3 & 1,00 & EURO & 15.070 & 15.061 & 14.236 \\
\hline \multicolumn{5}{c}{ Source: $w w w . b i . g o . i d ~($ processed data, 2017) }
\end{tabular}

Table 2 has shown the development of the foreign currency each year was increasing, except the value of the Euro against the rupiah was weakening each year, of course this would impact on companies that have conducted export and import transactions.

Exchange rate fluctuations could bring the impact of adding profits and could also have an impact on suffering more losses. The fluctuation of the rupiah exchange rate was caused by the demand of foreign currency to make payments on the sale and purchase transactions conducted by the manufacturing and mining industries and other companies and the rest was the people who have invested in foreign currency in order to expect future profits on the rupiah exchange rate fluctuation.

If we used the CAGR approach (Compound Annual Growth Rate) then the average return of IHSG since 19972015 was $12.84 \%$. This has indicated that JCI could grow $2-3 \mathrm{x}$ from the average of Indonesia's economic growth every year.

So the Composite Stock Price Index (IHSG) had moved stronger throughout January 2016, of course, this was a positive sign for manufacturing industries that would be able to increase their funding from their own shares and investors who have invested in their company's stocks, triggered by the stock buying action by the Investment managers and investors at the beginning of the year. Optimism for Indonesia's better economic growth was also expected to push the rate of IHSG to the end of this year. This was because the central bank of US, the Fed, had increased the fed funds rate from $0-0.25 \%$ to
$0.25-0.50 \%$ on December 16,2015 . The Fed also signaled it would raise its interest rate by four times in 2015 .

Based on the description of the background the researchers were interested in examining the "The Influence of Firm Size, Export Ratio, Earning Variability On Firm Value with Economic Exposure as Intervening Variable in the Manufacturing Industry Sector." The period was from 2011 to 2016.

\section{Problem Formulation}

Based on the research background that has been described above, the problems in this research are:

1. Does Firm Size impact the Firm Value through Economic Exposure?

2. Does Export Ratio impact Firm Value through Economic Exposure?

3. Does Earning Variability impact Firm Value through Economic Exposure?

4. Does Firm Size, Export Ratio, and Earning Variability impact simultaneously to Firm Value through Economic Exposure?

\section{LITERATURE REVIEWS}

\section{A. Firm Value}

The value of the firm is the investor's perception of the success of the company that can be attributed to the stock price and profitability [3]. Firm value can also be measured by using the fair value of the stock. For companies that have been public listed, the fair value of the stock is determined by the mechanism of demand and supply on the stock market, which is reflected in the listing price. According to Rakhimsyah and Barbara [4] the firm value is formed through indicators of market value of shares was strongly influenced by investment opportunities.

An assessment of relative share price attractiveness compared to the shares of rival companies provides managers with insights into the ease of attracting investment capital as well as the attractiveness of potential takeover bids. If the share price is trading lower than it should, based on the earnings expected, a company will make an attractive takeover budget. Bernard said that the price to earning ratio is the most popular metric of stock analysis and looks at the relationship between the stock price and the company's earnings [5].

Modigliani and Miller have a convincing argument that a firm cannot change the total value of its outstanding securities by changing the proportions of its capital structure [6]. In other words, the value of the firm is always the same under different capital structures.

The reason why most shareholders invest in a company is to maximize the return on their investment. Total shareholder return is a key measure as it represents the change in capital or value of a listed company over a period of time. Total shareholder return combines share price appreciation and dividends to show the total return to shareholders. 
Dividend usually refers to a cash distribution of earnings. If a distribution is made from sources other than current of accumulated retained earnings, the term distribution rather than dividend is used. The most common type of dividend is in the form of cash. When public companies pay dividends, they usually pay regular dividends four times a year. Sometimes firms will pay a regular cash dividend and an extra cash dividend. Another type of dividend is paid out in shares of stock. This dividend is referred to as a stock dividend [7].

Total shareholder return is an easy way to compare performance of similar companies. Companies often use total shareholder return as a key measure to determine senior executive compensation, because total shareholder return focuses not just on improving the financial or stock performance of the firm but on putting it in reration to a peer group. The argument is that a company's stock might do well over a period of time but lag behind those of competitors or other organizations with a similar profile.

The existence of investment opportunities can give a positive signal about the company's growth in the future, so that will increase the stock price, then the firm value will also increase. The purpose of maximizing the firm value is related to financial decisions, so that every decision should be indicated by actions that can increase the stock price of the company.

\section{B. Economic Exposure}

Economic Exposure is the risk that a company's cash flow, foreign investment and earnings may suffer as a result of fluctuating foreign currency exchange rates. In other words, the economic exposure is measuring changes in exchange rates that influence firm value that is measured in the present value of the expected future cash flows / focused on the impact of exchange rate changes on firm value. Exposurebased on market values assumes that the company's financial objective is to maximize shareholder's wealth.

One of the most significant complications of international finance is foreign exchange. The foreign exhange markets provide important information and opportunities for an international corporation when it undertakes capital budgeting and financing decisions [8]. The foreign exchange market is undoubtedly the world's largest financial market. It us the market where one country's currency is traded for another's.

The foreign exchange market is an over-the-counter market, so there is no single location where traders get together. Instead, market participants are located in the major commercial and investment banks around the world. They communicate using computers, telephones and other telecommunication devices.

An exchange rate is simply the price of one country's currency expressed in terms of another country's currency. Exposure to exchange rate fluctuations is the sensitivity of changes in the real value of assets, liabilities or operating income declared in the domestic currency against unanticipated exchange rate changes [9]. Economic exposures focus on the impact of currency fluctuations on firm value. According to Mishkin that one of the most prominent theories of how exchange rates are determined is the theory of purchasing power of parity (PPP) [10]. PPP states that exchange rates between any two currencies will adjust to reflect changes in the price levels of the two countries. The theory of PPP is simply an application of the law of one price to national price levels rather than to individual prices.

\section{Firm Size}

Firm size is one of the decisive factors in the achievement of efficiency in its operations. In an industry there are firms of varying sizes. The firm refers to the business unit or undertaking which owns the plant, controls and manages it. There are standards to measure the size of a firm, such as capital invested, value of the product, volume of output, asset owned and the power used.

You [11] ini his paper gives a survey of the theories of the determinants of firm size and the distribution of firm sizes, with a special emphasis on small firms. He classified the diverse literature surveyed into four approaches: the conventional microeconomic approach (or the technological approach) in which firm size is determined by technical and allocation efficienty; the transaction cost approach (or the institutional approach) in which firm size is determined by transaction cost efficiency; the industrial organization approach in which firm size and its distribution (market structure) are determined by market power; and the dynamic models of the size distribution of firms, including stochastic models, life-cycle models and evolutionary models.

Bauman and Kaen classify firm size as technological, organization and institutional [12]. Technological theories focus on the production process and emphasize physical capital and economies of scale and scope of variable that determines optimal firm size and by implication profitability. Organizational theories tie profitability and size together with organizational transaction costs, agency costs and span of control costs. Institutional theories relate firm size to variables such as legal systems, anti-trust regulation, patent protection, market size and the development of financial markets.

Wahome, Memba and Muturi's recent work on the actively listed Egyptian corporations, the findings of the estimated model and the various other tests confirm the existence of a significant positive relation between firm size and the debtequity ratio [13]. The result also confirms the notion that large firms are employed more debt because these are less risky and diversified in nature (static trade-off theory). In addition, large firms are preferred to issue more debt because it reduces direct bankruptcy costs due to market confidence.

Firm Size to measure the company's economic scale if it is related to the level of corporate hedging costs. Big companies have higher access levels to hedge on each of their transactions compared to smaller companies. As a result, big firms are influenced lower by the exchange rate fluctuations than small firms, but in the development it is possible for smaller companies to be more active to hedge on each of their international transactions. Therefore, the firm size effect on the level of economic exposure experienced by the company can be positive or negative. 


\section{Export Ratio}

Export is a sale made to an abroad company. From the export level made by the company, indicated the level of international business involvement was undertaken by a company. Girma, Greenaway and Kneller have stated that exporting involves sunk costs, so some firms export while others do not. This proposition derives from a number of models of firm behavior and has en exposed to microeconometric analysis. Evidenc from the latter suggest that exporting firms are generally more productive than non exporters; they self select in that they are more productive before they enter export markets [14].

From the profits generated through these foreign transactions then if it was dominated the relevant country currency (in this case the rupiah), then if associated with exchange rate fluctuations will change. Changes will be positive if the currency of the origin country is depreciating, on the contrary if the company's currency of the origin country is appreciating then the company will incur losses. Jorion [15] indicated that the depreciation of dollar was positively related to export.

The export ratio is to measure the proportion of a firm's sale that are exported, which expresses export sales revenues as a fraction of total sales revenue. To the extent that overseas debts often take longer to collect than the money owed by domestic customer, a high export ratio can influence the debtors ratio.

\section{E. Earning Variability}

Earning variability is measured as the value of the standard deviation of price earning ratio (PER), where PER data can be daily, weekly, monthly, quarterly or yearly. PER is used by investors to predict the company's ability to generate profit in the future. Therefore, if the value of PER is higher, then the company is riskier.

It looks at historic performance and measures the price an investor is paying for IDR1 of the company's earnings. Alternatively, it could be expressed in the time it would take investors to earn back their initial investment in a company if this company keeps generating the same earnings that it did in the past year. A higher PER therefore it means that investors are paying more for each unit of net income, so the stock is more expensive compared to one with a lower PER.

The main problem with the PER is that it takes past earnings to come up with a current value. The past performance is not necessarily a guarantee for future performance. This is why investors increasingly look at the forward PER. This is particularly useful when the previous year's profits were distorted by events such as a large asset sale, a write down or when a company is emerging from a period of losses. Also, when looking at PER it is important to check the units of the ratio. Most reported PERs are in years, meaning the number of years to get the investors' money back assuming nothing changes.

Profit variability is also a risk to the company, so with increasing risk will increase the hedging activities performed by the company. In accordance with the theory of hedging optimization, the higher hedging activity is undertaken by the company then the smaller of the company's opportunity to be exposed by exchange rate fluctuations. Therefore, earning variability has a positive relationship with the economic exposure faced by the company.

\section{F. Conceptual Framework}

Based on the above theoretical basis and problem formulation, the researchers develop the research framework. The conceptual framework to be studied by the researcher is as the following.

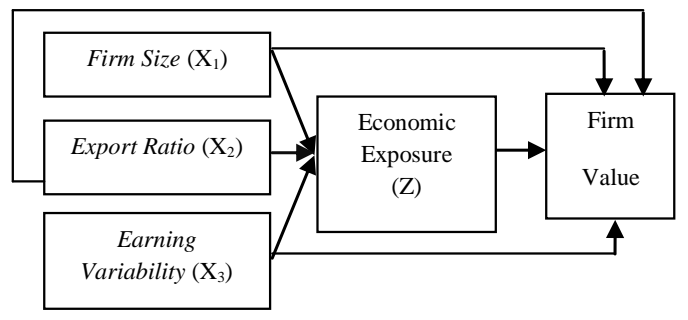

Figure 1 Conceptual Framework

\section{G. Research Hypothesis}

Based on the previous problem formulation, the hypothesis of this study are:

H1: Firm Size has impacted Firm Value through Economic Exposure.

H2 : Export Ratio has impacted Firm Value through Economic Exposure.

H3 : Earning Variability has impacted Firm Value through Economic Exposure.

H4 : Firm Size, Export Ratio, and Earning Variability have impacted Firm Value through Economic Exposure

\section{RESEARCH METHODS}

\section{A. Types and Nature of Research}

The type of this research is descriptive statistics research. The nature of this research is explanatory that intends to explain the position of the variables and the relationship between one variable with another variable [16].

\section{B. Population and Sample}

The population in this study were 138 manufacturing companies listed in the Indonesia Stock Exchange in the period of 2011-2016.

Samples were taken by using Purposive Sampling method with the following criteria: 
Table 3

Research Population Criteria

\begin{tabular}{|c|c|c|}
\hline \multirow[b]{2}{*}{ No } & \multirow[b]{2}{*}{ Company Characteristics } & Total \\
\hline & & $\begin{array}{c}\text { Manufacturing } \\
\text { Industry }\end{array}$ \\
\hline 1 & Total Companies & 138 \\
\hline 2 & $\begin{array}{l}\text { Companies that are late to publish the } \\
\text { complete annual financial report year } \\
2011-2016\end{array}$ & (4) \\
\hline 3 & $\begin{array}{l}\text { Companies that do not complete export } \\
\text { data for 2011-2016 }\end{array}$ & (2) \\
\hline & Total Sampel & 132 \\
\hline & Total Observation 132 X 6 & 792 \\
\hline
\end{tabular}

Source: www.idx.co.id, 2017 (processed)

Based on the predetermined criteria, the number of manufacturing companies listed on the Indonesia Stock Exchange which have met the sample criteria are 132 companies. This study has used a saturated sample by using a panel data analysis unit with a period of observation of six years from 2011-2016 and $n=132$ companies so that the number of observations are 792 observations.

\section{Operational Variable}

The operational definitions and measurements for each variable in this study are:

\section{1) Firm Size (X1)}

Firm Size reflects the size of the company based on its market capitalization. Big, well-established companies with high profitability and regular profits, can easily get public listed or get various external funds for their financing. Firm Size is represented by the natural logarithm of total assets.

Firm Size $=$ Ln(Total Asset $)$

The study of John and Adebayo [17] and Robert [18] have proved that big size firms have effected their profitability. Akinyomi Oladele John and Olagunju Adebayo through their research had concluded that firm size, both in terms of total assets and in terms of total sales has a positive effect on the profitability of Nigerian manufacturing companies.

Robert Kisavi Mule, Mohamed Suleiman Mukras and Onesmus Mutunga Nzioka had concluded in their research that there was a positive significant relationship between firm size and profitability.

\section{2) Export Ratio (X2)}

Exports are sales conducted by companies to overseas. From the level of exports conducted by the company can be known the level of international business involvement undertaken by the company. Profit generated through foreign transactions if denominated in the currency of the related country will change due to exchange rate fluctuations.

$$
\text { Export Ratio }=\frac{\text { Total Export }}{\text { Company's Total Asset }}
$$

3) Earning Variability (X3)

$$
\sqrt{ } \frac{\sum(\text { PERi }- \text { PER }) 2}{n-1}
$$

The earning variability is measured as the value of the standard deviation of price earnings ratio (PER). Profit variability is a risk of the company.

Earning Variability $=$

\section{4) Economic Exposure (Z)}

Economic exposure measures potential of the firm's profitability and reflects the changing market values as a result of exchange rate changes

$$
\beta_{0}=R_{i t}-\beta_{1} \Delta R_{\text {st }}+\beta_{2} R_{m t}+e
$$

\section{Firm Value (Y)}

The firm value in this study is proxied by Tobin's $Q$ to measure the success of management in the past operations and the future projection.

Firm Value (Tobin's Q)

$$
=\frac{(\mathrm{OSxP})+(\mathrm{D}+\mathrm{I})-\mathrm{CA}}{\mathbf{T A}}
$$

Where:

$$
\begin{array}{ll}
\text { OS } & =\text { Outstanding Share } \\
\mathrm{P} & =\text { Stock Price } \\
\mathrm{D} & =\text { Total Debt } \\
\mathrm{I} & =\text { Total Inventory } \\
\mathrm{CA} & =\text { Current Asset } \\
\mathrm{TA} & =\text { Total Asset }
\end{array}
$$

\section{5) Analysis Model}

Hypothesis testing is performed to answer the hypothesis in this study. Data analysis model has used path analysis, with the model as follows:

Sub Model $1=$

$\mathrm{Y}=\beta 1 \mathrm{X} 1+\beta 2 \mathrm{X} 2+\beta 3 \mathrm{X} 3+\varepsilon 1$

Sub Model $2=$

$Z=\beta 1 X 1+\beta 2 X 2+\beta 3 X 3$

$\mathrm{Y}=\beta 1 \mathrm{Z}$

\section{FINDINGS}

\section{A. Descriptive Statistics Analysis.}

In the Descriptive Statistics indicates the description of the research variables that shows the minimum value, maximum value, average value and standard deviation. In this study the standard deviation value is smaller than the average value so it can be concluded that the study is distributed normally.

\section{B. Inferential Statistics Analysis.}

Inferential statistical analysis has been done by doing classical assumption test. The aim of classical assumption test is to have a good dataset of enormous importance for applied economic research. The classical assumption tests consists of normality test, multicollinearity test, autocorrelation test and heteroscedasticity test, 
Normality test is used to determine if a data set is wellmodeled by a normal distribution and to compute how likely it is for a random variable underlying the data set to be normally distributed. The empirical distribution of the data should be bell-shaped and resemble the normal distribution.

\section{For normality test it can be seen at Normal P-P Plot Chart.}

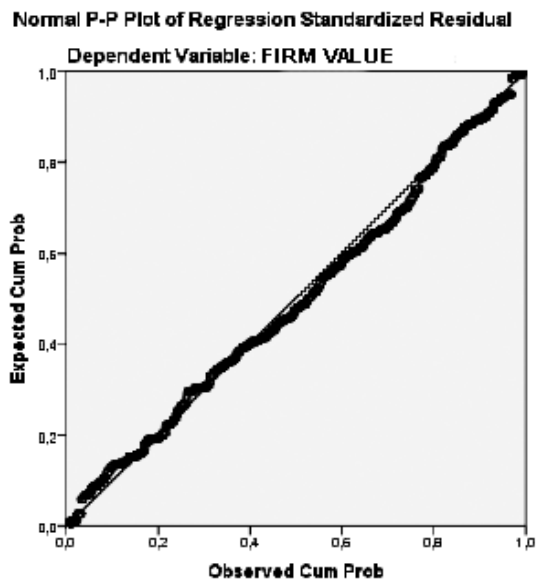

Figure 2 Normality Test

From the Normal P-P Plot chart has shown the spreading dots around the diagonal line, and the spreads follows the direction of the diagonal line. This means that the data have met the normality assumption, so the regression model is feasible to predict the economic exposure on the company based on the input of the independent variable.

Multicollinearity occurs when there are high correlation between two or more predictor variables because will create redundant information, skewing the results in a model.

Table 4 Multicollinearity Test

\begin{tabular}{cccc}
\hline & \multirow{2}{*}{ Model } & \multicolumn{2}{c}{ Collinearity Statistics } \\
\cline { 3 - 4 } & & Tolerance & VIF \\
\hline \multirow{3}{*}{1} & (Constant) & & \\
\cline { 2 - 4 } & Firm Size & 0,996 & 1,004 \\
\cline { 2 - 4 } & Export Ratio & 0,820 & 1,219 \\
\cline { 2 - 4 } & Earning Variability & 0,821 & 1,217 \\
\hline
\end{tabular}

Source: Output, data processed, 2016

Multicollinearity measurement in this study is seen from the tolerance value and variance inflation factor (VIF). If the tolerance value is $>0.1$ and the VIF value is $<10$ then the regression model is free from multicollinearity problem [19]. From the table 4 has shown that the data in this study is free from the multicollinearity problems.

Autocorrelation is where error terms in a time series transfer from one period to another. Researchers have used autocorrelation test by using Runs test, that is, by looking at the value of Asymp. Sig (2-tailed). If the value of Asymp. Sig (2-tailed) $>\alpha=5 \%(0.05)$ then it can be said that data do not have autocorrelation. Based on Runs Test with the value of Asymp. Sig (2-tailed) of $0.971>\alpha=5 \%(0.05)$ means that data do not occur auto correlation.

Heteroscedasticity is the error variance, or dependent scatter, within a minimum of one independent variable within a particular sample. These variations can be used to calculate the margin of error between data sets, such as expected results and actual results, as it provides a measure for the deviation of data points from the mean value.



Figure 3. Model of Heteroscedasticity Test

Heteroscedasticity test shows the spreading spots around the 0 point and does not form a pattern so this test is free from heteroscedastisity problem. Based on the above classical assumption test had shown the data were good.

Table 5 Equation of Regression Model Coefficients

\begin{tabular}{|c|c|c|c|c|c|c|}
\hline \multirow[b]{2}{*}{ Model } & & \multicolumn{2}{|c|}{$\begin{array}{l}\text { Unstandardized } \\
\text { Coefficients }\end{array}$} & \multirow{2}{*}{$\begin{array}{l}\text { Standardize } \\
\text { d } \\
\text { Coefficients } \\
\text { Beta } \\
\end{array}$} & \multirow[b]{2}{*}{$\mathrm{t}$} & \multirow[b]{2}{*}{ Sig. } \\
\hline & & $\mathrm{B}$ & 1. Error & & & \\
\hline \multirow[t]{4}{*}{1} & (Constant) & 0,071 & 0,070 & & 1,018 & 0,309 \\
\hline & Firm Size & $-0,001$ & 0,002 & $-0,007$ & $-0,222$ & 0,823 \\
\hline & $\begin{array}{l}\text { Export } \\
\text { Ratio } \\
\end{array}$ & 1,434 & 0,074 & 0,630 & 19,341 & 0,000 \\
\hline & $\begin{array}{l}\text { Earning } \\
\text { Variability }\end{array}$ & 0,084 & 0,013 & 0,208 & 6,390 & 0,000 \\
\hline a. De & lent Variab & Firm V & lue & & & \\
\hline
\end{tabular}
Source: Output, data processed, 2017

Based on Table 5 can be seen the equation of path analysis Model in this study is:

$Y=-0,001 X_{1}+1,434 X_{2}+0,084 X_{3}$

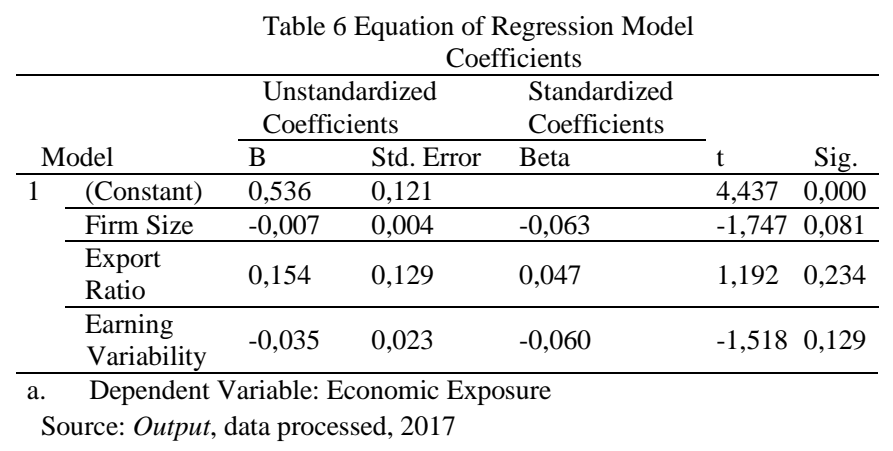

Based on Table 6 can be seen that equation of path analysis sub-Model II in this study is

$\mathrm{Z}=-0.007 \mathrm{X} 1+0.154 \mathrm{X} 2-0.035 \mathrm{X} 3$ 
Based on the explanations can be illustrated the path diagram in Figure 4.

\begin{tabular}{|c|c|c|c|c|c|c|}
\hline \multirow{3}{*}{\multicolumn{2}{|c|}{ Model }} & \multicolumn{5}{|c|}{ Coefficients } \\
\hline & & \multicolumn{2}{|c|}{$\begin{array}{l}\text { Unstandardized } \\
\text { Coefficients }\end{array}$} & \multirow{2}{*}{$\begin{array}{l}\text { Standardized } \\
\text { Coefficients } \\
\text { Beta }\end{array}$} & \multirow[b]{2}{*}{$\mathrm{t}$} & \multirow[b]{2}{*}{ Sig. } \\
\hline & & $\mathrm{B}$ & Std. Error & & & \\
\hline \multirow[t]{2}{*}{1} & (Constant) & 0,421 & 0,011 & & 36,858 & 0,0000 \\
\hline & $\begin{array}{l}\text { Economic } \\
\text { Exposure }\end{array}$ & 0,015 & 0,025 & 0,021 & 0,590 & $i 566$ \\
\hline
\end{tabular}

Table 7 shows the equation of second substructure of path analysis in this study is

$\mathrm{Y}=0.015 \mathrm{Z}$



Figure 4 Partial Significance Test

Based on Table 5 and Table 6 of the above regression equation, the regression model among independent variables (Firm Size, Export Ratio, and Earning Variability) and Economic Exposure variable as intervening and Firm Value as dependent variable are as follows:

\section{Firm Size Effect Firm Value through Economic Exposure.}

Based on the above chart can be concluded that the indirect effect is greater than the direct influence, so it can be concluded that Firm Size negatively effect Firm Value through Economic Exposure. The result is supported by the study of Gharaibeh and Sarea [20], Nur Anisa [21], Sri [22] and Henri [23].

Obeid Gharaibeh and Sarea had concluded in their study that firm size were significant influential of the firm's value. Their study had used natural logarithm of total assets (LNTA) as a proxy for size of the firm.

Nur Anisa in her research of the role of dividend payout ratio (DPR) to determine the influence of ROA and firm size on firm value has concluded that firm size has influenced significantly on the firm value. Sri Hermuningsih of her research entitles the influence of profitability, size on the firm value with capital structure as intervening variables has resulted that profitability and firm size have effected indirectly on firm value with capital structure as an intervening variables. Further, Henri of his study entitles the influence of firm size, profitability, dividend policy and investment decision on the firm value have concluded that firm size has influenced positively but insignificant on the firm value. In addition, Shabri has concluded that economic exposure has effected insignificantly and positively on firm value [24].

\section{Export Ratio Effect Firm Value Through Economic Exposure.}

Based on the above chart can be concluded that the direct influence is greater than indirect influence, so it can be concluded that Export Ratio has a positive significant effect on Firm Value.

Previous study has not been using export ratio variable effects the firm value. However, there are only results by Ari [25] and Jimmy [26]. The result of Jimmy's study has shown that the export has influenced significantly and positively on foreign exchange reserves. Here, it is assumed that foreign exchange reserves are value of a country. Meanwhile, Ari's study has concluded that exchange rate exposure in long term or short term has influenced significantly and negatively on the export of Indonesia.

\section{E. Earning Variability Effect Firm Value through Economic Exposure.}

Based on the above chart can be concluded that the direct influence is greater than indirect influence, so it can be concluded that Earning Variability has a positive significant effect on Firm Value. The result is supported by Sugeng [27], Nur [28], Widhiastuti [29], .

Sugeng in his research of the influence of asset growth, leverage and earning variability on stock's beta at Jakarta Islamic Company listed in the Indonesia Stock Exchange has concluded that earning variability has effected significantly on stock's beta.

Nur has done a study of the influence of inflation, liquidity and earning variability on stock's beta on the manufacturing companies listed in the Indonesia stock exchange period of 2010 to 2013 has concluded that earning variability has influenced significantly on stock's beta whileas inflation and liquidity has not effected significantly on stock's beta. Further, the study was performed by Wiadhiastuti, Ni luh Putuand Latrini Made Yeni had concluded that the increase of Return on Asset (ROA) will increase the firm value, the better management of intangible asset will increase firm value. The disclosure of corporate social responsibility can moderate the impact of return on asset on firm value, but the disclosure of corporate social responsibility can not moderte the impact of intangible asset on firm value.

\section{F. Firm Size, Export Ratio and Earning Variability Effect Simultaneously To Firm Value Through Economic Exposure.}

Based on the above chart can be concluded that the direct influence is greater than indirect influence, so it can be concluded that Firm Size, Export Ratio, and Earning Variability simultaneously have a positive effect on Firm Value. 
In addition to the findings, for further researcher need to consider the variable of debt ratio, corporate governance and corporate social responsibility into their research. According to Cuong's study has shown that there was triple threshold effect exists between debt ratio and firm value [30]. Jo and Harjoto have concluded that CSR engagement positively influences firm value measured by industry-adjusted Tobin's q [31].

Table 8 F Test

\begin{tabular}{cccccccc}
\multicolumn{8}{c}{ ANOVA $^{\mathrm{a}}$} \\
\hline & \multicolumn{1}{c}{ Sum of } & \multicolumn{2}{c}{ Mean } \\
Model & Squares & df & Square & F & Sig. \\
\hline \multirow{2}{*}{1} & Regression & 13,336 & 3 & 4,445 & 126,524 & $0,000^{\text {b }}$ \\
\cline { 2 - 7 } & Residual & 27,018 & 769 & 0,035 & & \\
\cline { 2 - 7 } & & & & & & \\
\hline
\end{tabular}

a. Dependent Variable: Firm Value

b. Predictors: (Constant),Earning variability, Firm Size, Export Ratio Source : Output, data processed, 2017

Table 8 shows the $\mathrm{F}$ test using multiple linear regression that aims to know and analyze the influence of Firm Size, Export Ratio, and Earning Variability simultaneously to firm value. The results of this study indicate that independent variables has influenced significantly to the value of the firm.

Table 9 Determination Test

Model Summary

\begin{tabular}{|c|c|c|c|c|}
\hline \multicolumn{5}{|c|}{ Model Summary } \\
\hline Model & $\mathbf{R}$ & R Square & $\begin{array}{c}\text { Adjusted R } \\
\text { Square }\end{array}$ & $\begin{array}{l}\text { Std. Error of } \\
\text { the Estimate }\end{array}$ \\
\hline 1 & $0,575^{\mathrm{a}}$ & 0,330 & 0,328 & 0,1874399 \\
\hline
\end{tabular}

Source: Output, data processed, 2017

Based on Table 9, the coefficient of determination $\left(\mathrm{R}^{2}\right)$ shows at the Adjusted R-Square column. The value of Adjusted R-Square is 0,328 means that the independent variables are simultaneously effect the dependent variable of $32.8 \%$, the remaining of $67.2 \%$ is influenced by other variables that are not described in this study.

\section{CONCLUSIONS}

The result of the research showed that the variables of Firm Size, Export Ratio and Earning Variability direct positive influence on Firm Value. Export Ratio and Earning Variability direct positive influence on Firm Value. Firm Size indirect positive influence on Firm Value. The variables of Exposure Economic as intervening variables to explain influence Firm Size on Firm Values.

\section{REFERENCES}

[1] M. D Pritamani., Shome, D. K., \& Singal, V. Foreign Exchange Exposure of Exporting and Importing Firms. Journal of Banking and Finance Vol 28, No.1, 2004.

[2] Anggraeni. "The Foreign Exchange Exposure pada Bank-Bank Go Public di BEJ". Jurnal Ventura, STIE Perbanas Surabaya, Vol 7, No 2. 2004.

[3] Sari, Dessy Handa., Djazuli, Atim., Siti, Aisjah. "Determinan Struktur Modal dan Dampaknya terhadap Nilai Perusahaan (Studi pada Perusahaan Makanan dan Minuman di Bursa Efek Indonesia)". Jurnal Aplikasi Manajemen 11 no. 1, pp. 77-84, 2013.

[4] Rakhimsyah, Leli Amnah dan Barbara, Gunawan. Pengaruh Keputusan Investasi, Keputusan Pendanaan, Kebijakan Dividen dan Tingkat Suku Bunga terhadap Nilai Perusahaan. Jurnal Investasi. Vol. 7 No. 1, 2011.

[5] Bernard Marr, Key Performance Indicators: The 75 Measures Every Manager Needs To Know, pp. 79, 2012.

[6] F. Modigliani and M. Miller, The Cost of Capital, Corporate Finance and The Theory of Investment, American Economic Review, vol. 48, no. 3, pp. 261-297, June 1958.

[7] Stephen A. Ross, Randolph W, Westerfield, Jeffrey F. Jaffe, Rodziah Abd Samad, Shelia Christabel, Corporate Finance, Second Edition, McGraw Hill, Malaysia, pp. 319, 2016.

[8] Stephen A. Ross, Randolph W, Westerfield, Jeffrey F. Jaffe, Rodziah Abd Samad, Shelia Christabel, Corporate Finance, Second Edition, McGraw Hill, Malaysia, pp. 417, 2016.

[9] M. Levi, Keuangan Internasional. Buku Satu, Terjemahan dari : Handoyo Prasetyo. Penerbit: Andi dan Mc. Graw Hill Inc. Yogyakarta, 2001.

[10] Frederic S. Mishkin, The Economics of Money, Banking and Financial Markets, Eleventh Edition, Pearson Education Limited, USA, 2016.

[11] I. J. You, Small Firms In Economic Theory, Cambridge Journal of Economics, Vol. 19, pp. 441-462, 1995.

[12] H. D. Bauman and F. R. Kaen, Firm Size, Employees and Profitability in U.S. Manufacturing Industries. Social Science Research Network, 2013.

[13] Michael Njogu Wahome, F. Memba, Willy Muturi, The Effects of Firm Size and Risk on Capital Structure Decisions of Insurance Industry in Kenya, International Journal of Scientific and Research Publication, Vol. 5, Issue 8, 2015.

[14] Sourafel Girma, David Greeaway and Richard Kneller, Does Exporting Lead to Better Performance? A Microeconometric Analysis of Matched Firms, Research Paper Series, Interationalisation of Economic Policy Programme, 2002.

[15] P. Jorion, The Exchange-Rate Exposure of U.S. Multinationals. The Journal of Financial and Quantitative Analysis, Vol. 26, No 3, 1990.

[16] Erlina, Metodologi Penelitian. Cetakan Pertama: ISBN: 979 458. Art Design, Publishing \& Printing. Medan, 2011.

[17] Akinyomi Oladele John and Olagunju Adebayo, Effect of Firm Size on Profitability: Evidence from Nigerian Manufacturing Sector, Prime Journal of Business Administration and Management, pp. 1171-1175, 2013.

[18] Robert Kisavi Muli, Mohamed Suleiman Mukras and Onesmus Mutunga Nzioka, Corporate Size, Profitability and Market Value; An Economic Panel Analysis of Listed Firms in Kenya, European Scientific Journal, Vol. 11. No. 13, pp. 376-396, 2015.

[19] Imam Ghozali, Aplikasi Analisis Multivariate dengan Program IBM SPSS 21 Up Date PLS Regresi, Cetakan Ketujuh: ISBN: 979.704.015.1. Penerbit: Badan Penerbit Universitas Diponegoro, Semarang, 2013.

[20] Ahmad Mohammad Obeid Gharibeh and Adel Mohammed Sarea, The Impact of Capital Structure and Certain Firm Specific Variables On The Value of The Firm: Empirical Evidence From Kuwait, Corporate Ownership and Control, Vol 13 Issue 1, pp. 1191-1200, 2015.

[21] Nur Anisa and Anang Subardjo, The Role of Dividend Payout Ratio in Determining the Influence of Return On Asset and Firm Size on Firm Value, Jurnal Ilmu dan Riset Akuntansi, Vol. 3, No.6, Surabaya, 2014.

[22] Sri Hermuningsih, The Influence of Profitability, Size on Firm Value with Capital Structure as Intervening Variable, Jurnal Siasat Bisnis, Vol. 16, No. 2, pp. 23-242, 2012. 
[23] Henri Dwi Wahyudi, Chuzaimah and Dani Sugiarti, Firm Size, Profitability, Dividend Policy and Investment Decision Effect Firm Value, Jurnal Manajemen dan Bisnis, Vol. 1, No. 2, pp. 156-164, 2016.

[24] M. Shabri Abd. Majid, Zaida Rizq Zainul and A. Syakir Jalil, An Empirical Analysis of Economic Exposure And Its Determinants of The Miscellaneous Companies in Indonesia, Proceedings The $3^{\text {rd }}$ Annual International Conference Syih Kuala University,2013.

[25] Ari Mulianta Ginting, The Influence of Exchange Rate On Indonesia's Exports, Buletin Ilmiah Litbang Perdagangan, Vol. 7, No. 1, Jakarta, 2013.

[26] Jimmy Benny, Export and Import Effect On Foreign Exchange Reserves Position In Indonesia, Jurnal EMBA, Vol. 1, No. 4, Manado, pp. 14061415, 2013.

[27] Sugeng Priyanto, The Influence of Asset Growth, Leverage and Earning Varibility On Stock's Beta of Islamic Jakarta Companies Listed at Indonesia Stock Exchange, Jurnal Ekonomika dan Manajemen, Vol. 6, No. 1, Jakarta, pp.44-62, 2017

[28] Nur Ridwan and Nuramalia Hasanah, The Influence of Inflation, Liquidity, Earning Variability On Stok's Beta At Manufacturing Companies Listed At Indonesia Stock Exchange Period of 2010 - 2013, Jurnal Wahana Akuntansi, Vol.10, No. 1, Jakarta, pp. 88-107, 2015.

[29] Widhiastuti, Bi Luh Putu and Latrini Made Yeni, The Influence of Return On Asset and Intangible Asset On Firm Value With Corporate Social Responsibility as Moderating Variable, Jurnal Akuntansi Universitas Udayana Vol. 11, No. 2, pp. 370-383, 2015.

[30] Cuong, Nguyen Thanh. "Threshold Effect of Capital Structure on Firm Value: Evidence from Seafood Processing Enterprises in the South Central Region of Vietnam". International Journal of Finance \& Banking Studies 3 no.3: 14-29, 2014.

[31] Hoje Jo and Maretno A. Harjoto. Corporate Governance and Fir Value: The Impact of Corporate Social Responsibility. Journal of Business Ethics 103:351-383, 2011. 